\title{
Prospective English Teachers' Perspective on the Teaching Materials of Translation as Profession Subject
}

\author{
DOI: https://doi.org/10.47175/rielsj.v1i3.137
}

\author{
| Masitowarni Siregar ${ }^{1^{*}}$ \\ 1,2,3 Department of English \\ Language and Literature, Medan \\ State University, Indonesia \\ "masitowarnisiregar@unimed.ic.id
}

\begin{abstract}
Universally, the need for translator keeps increasing. This is due to the wider contact globally among countries. More common issue are also faced by countries in general. Therefore translation is required to transfer the meaning of how one issue is handled in one country and how is it in another. Based on these universities try to accommodate these needs by providing the subject of Translation in the curriculum. The objective of this study is to find out the prespective of prospective English teachers on the materials needed for Translation as Profession Subject.This research utilized Research and Development design implemented in 3 stages. First stage is identifying existing situation. The second stage is developing the material. The third stage validation of the product. The result of the validation shows that the book is valid with the average score is 4.30. The material was uploaded to Faculty of Languages and Arts Online System to be use din the teaching and learning process.

KEYWORDS

professional translation; teaching materials; prospective English

teachers
\end{abstract}

\section{INTRODUCTION}

In facing the current era of globalization, the development of language translation is urgently needed (Pro Translation, 2014). This is due to the increasing number of sectors that require translation services in the academic, business, economic, and social fields as a form of international relations between a country and other countries that use English as an international language. Thus, the ability to translate must continue to be improved because it would be very risk if then language translation was carried out by people who were not competent in thei rfield. This can have an impact on business or business damage due to meanings that are misunderstood or misinterpreted by the translators. So, it is hoped that every graduate majoring in Language, including English must have the ability to translate from the source language (Indonesian) to the target language (English) and vice versa. According to the Cabinet Secretary, Yuli Harsono, in his opening remarks at the Socialization of Translator's Functional Position at the Aston Hotel, Tanjung Pinang, Riau Islands, Thursday (21/4) emphasized severaltranslator functions, including, Written and oral communication bridges between relevant agencies and their international partners; Supporting the promotion of Indonesia's potential through translation of brochures / articles on the websites of related agencies, so that the international community is interested in investing in or visiting Indonesia; and Preserving local language andculture.

Furthermore, the government has implemented a policy through the State Secretariat that recruits bachelor (S1) English graduates both for Education and Non- Education to become translators and have the status of Civil Servants. This aims to increase the potential of the nation's children in helping the development of a nation. This has clearly been conveyed to 
Medan State University as one of the universities that has an English Language and Literature Department as an effort to disseminate policies carried out by the State Secretary.

Therefore, English students are not only required to master English but also have the ability to translate a language. This is realized by the existence of the Translation course at the Department of English Language and Literature, State University of Medan.

The "Translation" course is a compulsory subject that is present in almost all English Literature and English Language Education courses at leading universities in Indonesia. It is noted, for example, that in the latest curriculum, the English Education Study Program of the State University of Medan has Translation in English Anguage Tecahing (in ELT) and Professional Translation courses each with a weight of 4 credits. Likewise, in the English Literature Study Program, State University of Medan, there are a number of Translation courses with a weight of 10 credits. The English Language Education Study Program and the English Literature Study Program both make Translator a Profile of the Graduates of the Study Program.

Likewise, the English Literature Study Program of Gadjah Mada University divides the "Translation" course into two semesters, namely in semester 3 (English- Indonesian Translation) and 5 (Indonesian-English Translation), with a weight of 3 credits each (english.fib. ugm.ac.id). The English Literature Study Program of Sanata Dharma University, Yogyakarta, has courses "Recent Issues in Translation", "Register Translation" and "Simultaneous Interpreting" with total credits of 10 (Editors, 2016: 48- 50). In addition, there are also English Literature study programs that place the "Translation" course as an elective or elective course, such as at the State University of Malang.

Regardless of the different naming and credit load of each college, it can be generally agreed that the "Translation" course is an important skill course to be given to English Language (and Literature) students. The skill of translating text both from English to Indonesian and vice versa, as well as from various scientific fields, is one of the competencies to be achieved.

Professional Translation Courses in the English Language Education Study Program have appeared in the 2018 KKNI Curriculum for the first time. In 2020, this course is the second time this course has been introduced in the Odd semester. Considering that this course has only just emerged, so far there has been no validated teaching material to achieve the objectives of the course. For this reason, this study aims to develop Professional Translation Online Teaching materials. Teaching Materials Online courses are of course very much needed during the current Covid-19 Pandemic where online-based learning. Likewise, since 2017 Unimed has made a policy regarding SIPDA and at the Faculty of Language and Arts it is called FBS-E-Learning. Given the importance of competence, which presupposes the correct skills and knowledge, in the field of translation ("skills and knowledge" are two key words in the IQF), teaching methods and materials for the "Translation" courses hould also be prepared in such a way that takes into account the basic things, such as precise knowledge regarding the nature of language and the function of translation (philosophical-theoretical aspects), the needs of graduate users (practical-economic aspects), and the interests and talents of students (participatory pedagogical aspects). These three things must not only exist and be developed in the teaching methods and materials of the "Translation" course but, more importantly but often overlooked by teachers and syllabus compilers, a balance must be found in order to be effective. Being effective here means achieving why KKNI and what is the relationship between KKNI and teaching the "Translation" course? The IQF is a systemized and structured effort to measure the qualifications of Indonesian human resources so that they can compete and excel in the Southeast Asian context and even more 
broadly.

Some aspects of the substance of the core translation course teaching materials that have not been fully developed/presented/covered in the RPS include: (a) text analysis in translation, and (b) various theoretical aspects of translation (translation strategies/techniques) that can help students as candidates translators in overcoming text translation problems (Newmark, 1988; Munday, 2001), and (c) the use of web-based technology (WBL). Therefore, research on the development of E-Leraning-based teaching materials is very relevant and important because it is closely related to two main things: (1) collective efforts globally to present various teaching materials (teaching), learning (learning). Therefore, translation as profession teaching materials are needed in improving the translation skills of English students so that later they will be able to meet the needs of the times for translation itself.

Based on the demands that must be faced regarding the improvement of translation skills in English that have been described above, the formulation of this research problem is: How to develop teaching materials for E-Learning-based Professional Translation courses in the English Education Study Program, Department of English Language and Literature, FBS Medan State University?

\section{LITERATURE REVIEW}

\section{Translation}

Translation is a transfer of meaning from one language to another (Siregar,2019). Translation can function as a professional function where the process is an agreement between the translator and the user of the translation service itself. Where the agreement will end in the translation service fee itself. Therefore, translation as a profession is very important for students to master so that it can improve the quality of the translation itself.

The "Translation" course is a compulsory subject that is present in almost all English Literature and English Language Education courses at leading universities in Indonesia. It is noted, for example, that in the latest curriculum, the English Education Study Program of the State University of Medan has Translation in English Anguage Tecahing (in ELT) and Professional Translation courses each with a weight of 4 credits. Likewise, in the English Literature Study Program, Medan State University, there are a number ofT ranslation courses with credit weight. Th eEnglish Education Study Program and the English Literature Study Program both install a Translator as a Profile of the Graduates of the Study Program.

\section{Principles and Procedures for Developing Teaching Materials}

There are three principles needed in the development of teaching materials (Sadiman, et al., 2003). The three principles are relevance, consistency and sufficiency. Relevance means related or closely related. Consistency means regularity - fixed. Adequacy means that quantitatively the material is sufficient to study.

There are several procedures that must be followed in developing teaching materials (Sadiman, 2004). The procedures include: (1) understanding content standards and graduate competency standards, syllabus, semeter programs, and lesson plans; (2) identify the type of learning material based on the understanding of the first point; (3) carry out material mapping; (4) determine the form of presentation; (5) preparing the structure (framework) of presentation; (6) reading source books; (7) drafting (blurring) teaching materials; (8) revising (editing) teaching materials; (9) testing teaching materials; and (10) revising and writing the final (finalization). 
Another thing that is no less important is that in preparing teaching materials, it is necessary to pay attention to the suitability of the materials, the suitability of the relevant methods and media, and to support the learning process. According to Tarigan and Tarigan (1986: 20)the criteria for studying teaching materials include: (1) the applicable curriculum; (2) subject characteristics (relevant science); (3) the relationship between curriculum, subjects, and teaching materials; (4) basics of developing teaching materials; (5) quality of teaching materials; (6) principles of workbook development; and (7) workbook selection. The assessment of teaching materials according to Supriadi (2001:9) includes: "the quality of the book content, conformity to the curriculum, the language used, including its presentation and readability, graphics, and book safety".

\section{Online Learning System (E-learning) Medan State University}

The advancement of technology has a significant impact on all sectors, from education, economy, politics, and society. In increasing the progress of education as one of the most important sectors in the development of a nation, it is necessary to increase innovation in a learning process which aims to increase thea bility of students to be more active, creative, and independent. E-learning is a way to develop student abilities because in E-learning students are required to always be active, creative, and independent students regardless of various learning problems such as the absence of students or lecturers; limited time and space; as well as various of the rissues. Thus,E-learning is an activity that can overcome these various problems.

Since 2007 the State University of Medan (Unimed) has used online learning media or elearning. The system used is SIPOEL (System Portal Electronic Learning). Now e-learning is being renewed and replaced by SIPDA(Online Learning System). This e-learning system is adapted to the latest technological developments. The application used is open source based and supports mobile devices. The use of e-learning also aims to accelerate the learning process. The following is a display of the online learning systemat the State University of Medan which will be used as a medium for developing teaching materials for the Translation as Profession Course.

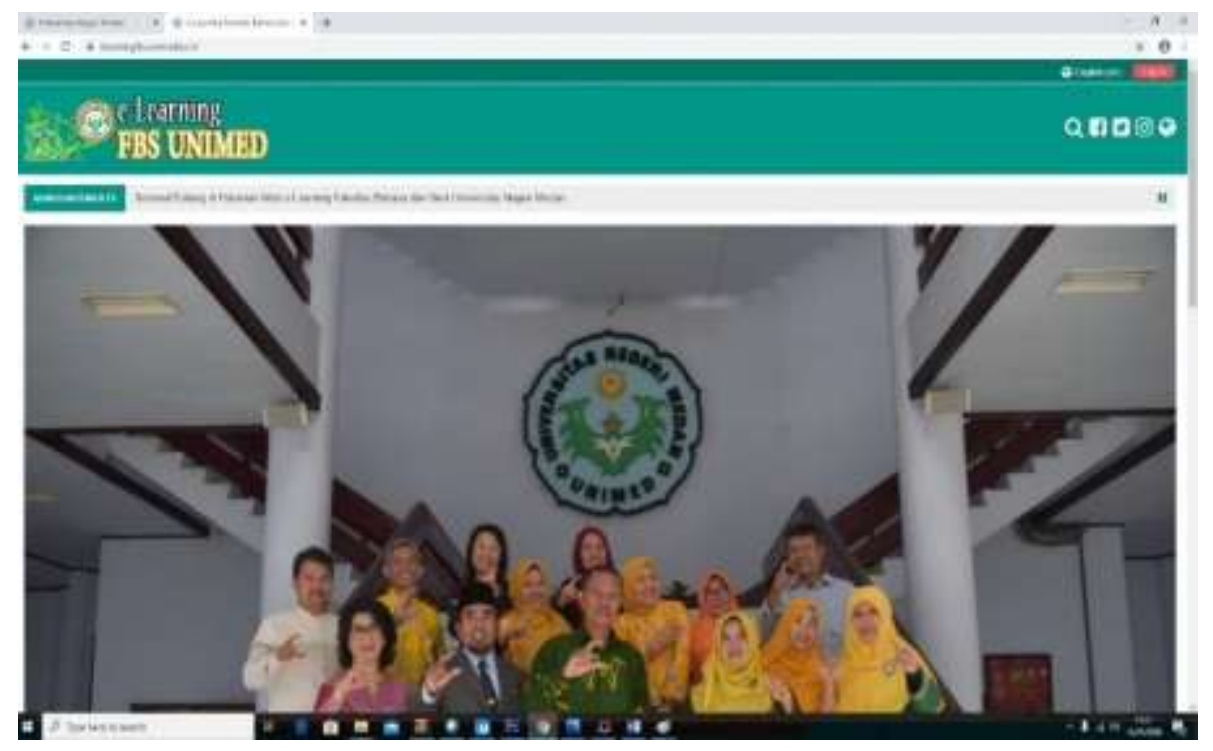

Figure 1. Home Views 




Figure 2. Login Display

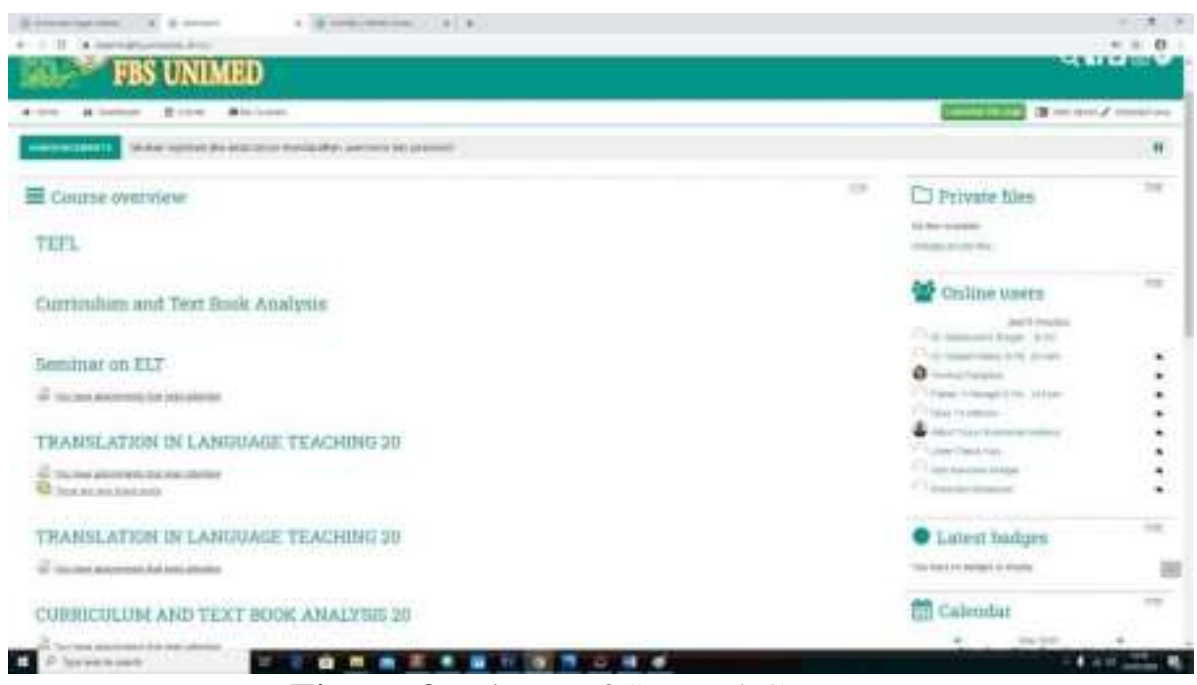

Figure 3. Views of Several Course

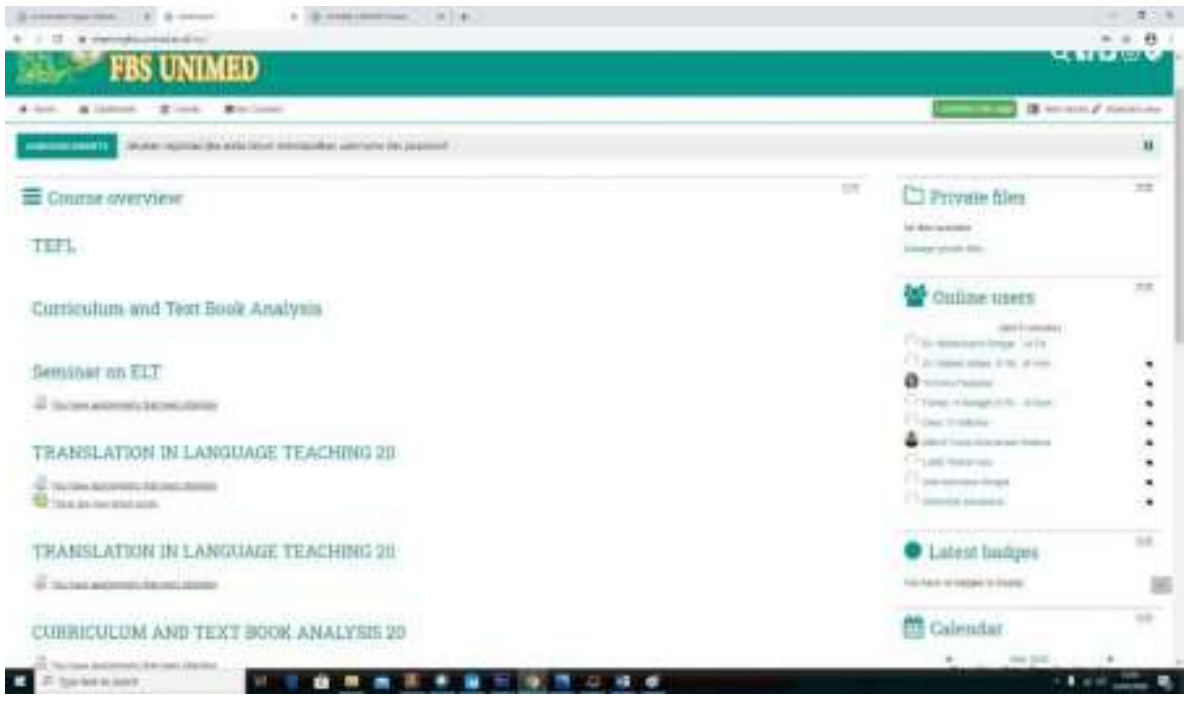

Figure 4. Display of Translation as Profession Course 


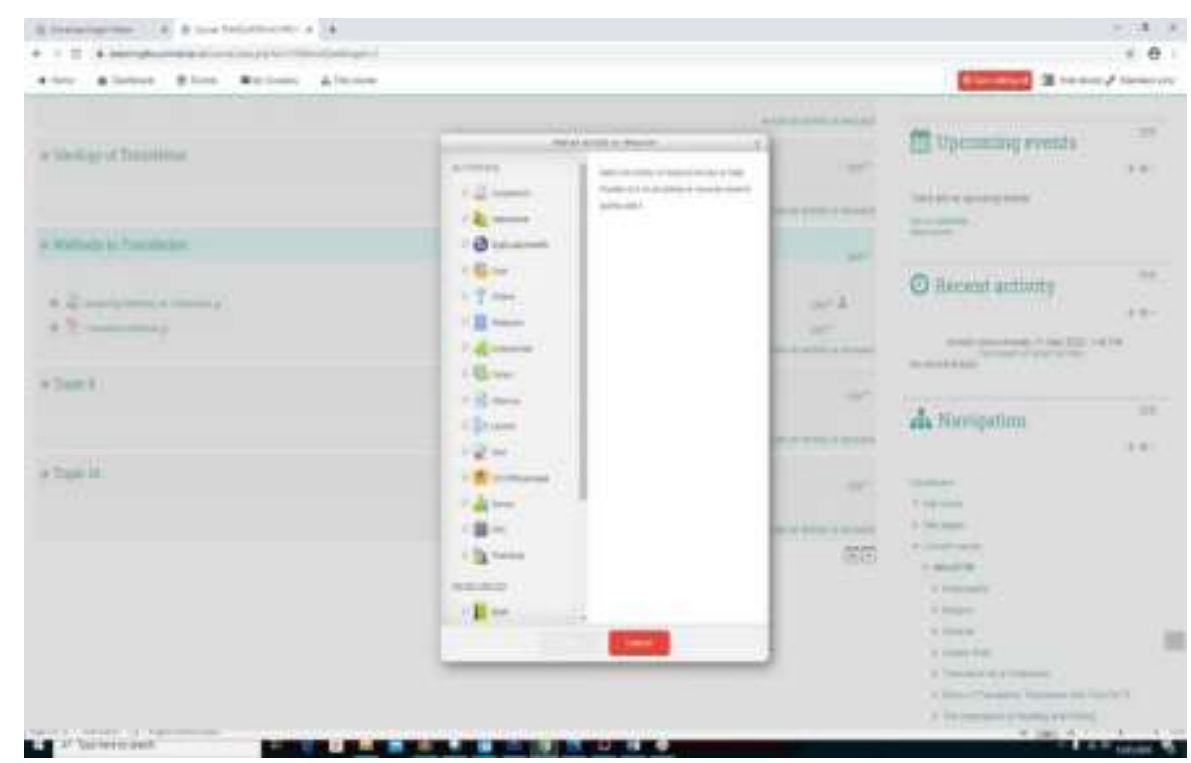

Figure 5. Display of Translation as Profession Learning

Bigg (2003), as quoted by Kelly (2005, p. 85), argues that educational technology is an effort to remind lecturers / tutors that the purpose of its use is to improve the quality of learning, not to provide more information nly. In the context of training programs for prospective translators, according to Kelly, the new technology is not only related to its use for teaching and learning purposes but also how to help students apply it in text translation activities.

To strengthen the theoretical basis mentioned above, some research on teaching translation courses via the web needs to be presented here. For example, research conducted by Micu and Sinu (2012). They examined the benefits of using a web-based program to teach specialized translation in economics and law. The focus of this study is translation as a process and translation as a product that can be assessed for quality.

Duan (2011) also examines the teaching of web-based English-Chinese translation courses. He uses a task-based approach in teaching these courses. One of the research findings is that teaching translation courses via the web can improve students' ability to translate texts, including access to course content and the teaching process.

\section{Learning Theory}

The development of teaching materials for the Professional Translation course is based on three major theories of learning, namely behaviorism, cognitivism, and constructivism (Davidson-Shivers \& Rasmussen, 2006: 40), as shown in Figure 6 below.



Figure 6. Principles in Learning Theory 
These three learning theories are very relevant to the development of Translation as Professional Teaching Materials as a skill to translate text (behaviorism: practice, reinforcement, active learning) which is based on general knowledge and theoretical knowledge of translation (cognitivism: learner-centered, meaningfulness, prior knowledge and active learning) which Is the napplied in the practice of translating texts professionally, the essence of which is how the meanings in the source text and target texts and cross-cultural empirical experiences are combined into one (constructivism: learning social contexts). In other words, the activities / practices of translating text from the source language to the target language that require bilingual knowledge.

\section{Translation Theory versus the Practice of TranslatingText}

Referring to the curriculum design process in general, including the English Language Education Undergraduate Study Program curriculum, designing text translation competence (design activities) is one of the important elements after identifying student profiles and instructional needs and before designing an assessment instrument (designing assessment). There are several aspects related to the design of these activities, namely: (1) theory/practice, (2) language learning/translation, (3) sequence of activities - tasks and projects, (4) criteria for selecting text (Kelly 2005: 113-128).

Curriculum experts, especially in the field of translation, have long debated about what should come first, whether the theory of translation (theory of translation) or the practice of translating texts (translation practice). For those who choose a deductive approach, of course, translation theory should be taught first before practicing translating a text which is full of translation problems. On the other hand, for those who choose an inductive approach, the practice of translating texts is given before the theory of translation which serves to solve translate on problems. Whatever approach is chosen, it actually depends on the student's learning styles, although the inductive approach guarantees deeper learning.

However, the Development of Teaching Materials adopts a deductive approach based on the one thought that translation theory is needed by a translator when he faces problems of translating texts. Therefore, the part of the key instructions fortranslation

/alternative translation answers in the training section in the RPS for the Translation as Profession course needs to be enriched with explanations / theoretical explanations of translation (translation theory), especially translation techniques that can help students overcome problems. Text translation.

According to Kelly (2005: 115-117), the sequence of activities to translatetexts should start with task-based approaches and end with project-based approaches. With this flow, student autonomy will increase, as can be seen in the following Chart 1.Task- based approaches Project-based approaches. With this flow, student autonomy will increase, as seen in Chart 1 below.

Task-basedapproaches

Project-basedapproaches

Increasing student autonomy

Chart 1. Student Autonomy and Appropriate Teaching Approaches

A specific text translation task-based approach can be found in the Exercise section of the Translation as Profession course. Increased autonomy for students in undergoing the study 
period ends with a translation portfolio (Kelly 2005: 138-139) in the form of a scientific work (karil) in the field of translation which provides more flexibility for students to choose their own English text to be translated into language. Indonesia and then given comments / justifications regarding the reasons for selecting certain equivalents in the translated text (project-based approaches).

The selection of various types of text to be translated (TSU) isofgreat concern in developing training programs for prospective translators.Kelly (2005: 117-127) proposes several criteria in selecting TSu types: (a) professional realism which refers to the authenticity of texts and other teaching materials, realism of translation situations, professional ethics, professional market; (b) pedagogical progressi on which includestext types, prototypical discourses, content acceptability, acceptability of reliable documentation, student interest and motivation, and feasibility. Some of the latter aspects are covered in the first research objectives (identification of TSu types), second (social objectives and functions of TSu), third (linguistic features and terminology in TSu), and fourth (structure of TSu).

\section{RESEARCH METHODS}

This research design is included in the category of research and development (research and development) as stated byBorg \& Gall (1983), namely a a process to develop a new product in the form of Professional Translation course materials to improve the product of teaching materials that are still very simple into teaching materials that can be scientifically justified. The research method used is mixed methods: qualitative and quantitative, as suggested byCreswell (2003), Silverman \& Marvasti (2008). The Fishbone Diagram is used to describe the stages of this research (Davidson-Shivers \& Rasmussen 2006) and the R\&D model (Borg \& Gall 1983).

The first stage- At this stage a survey and evaluation will be carried out for 1) mefind out the objective conditions regarding the teaching materials for the Translation as Profession course 2) to obtain data and information regarding E-Learning-based course teaching materials for students majoring in English. Output: E-Learning-based teaching materials for students majoring in English required.

Second stage is designing and developing Translation as Profession teaching materials based on E-Learning for students majoring in English. In the process of developing ELearning-based teaching materials for students majoring in English, reviewing assessment instruments by peers, and revising E-Learning-based teaching materials for students majoring in English. Output: E-Learning-based teaching materials for students majoring in English that have been reviewed by peers

The third or final stage is the validation of Translation as profession teaching materials based on E-Learning for students majoring in English by a team of experts. The expert team consist experts in the field of Translation. Finaloutput: expertly tested teaching materials.

\section{Research Sites}

This research was carried out in the English Education Study Program, English Language and Literature Department, Language and Arts Faculty, Medan State University.

\section{Data Collection Technique}

Data collection for the development of teaching materials for the Professional Translation course includes: (1) conducting an instructional needs analysis; (2) designing the Translation as Profession teaching materials. To obtain these data (qualitative and quantitative), several 
techniques will be used (interview techniques, observation techniques, and survey techniques through written / online questionnaires and documentation techniques) and types of research instruments.

\section{Data Collection Instruments}

The data collection instruments consist of documentation tools, interview guides, and questionnaires.

\section{Data Analysis Technique}

The analysis technique uses a qualitative descriptive analysis technique

\section{Research Paradigm}

Based on the descr iption above, the activities are presented in the flow chart below:

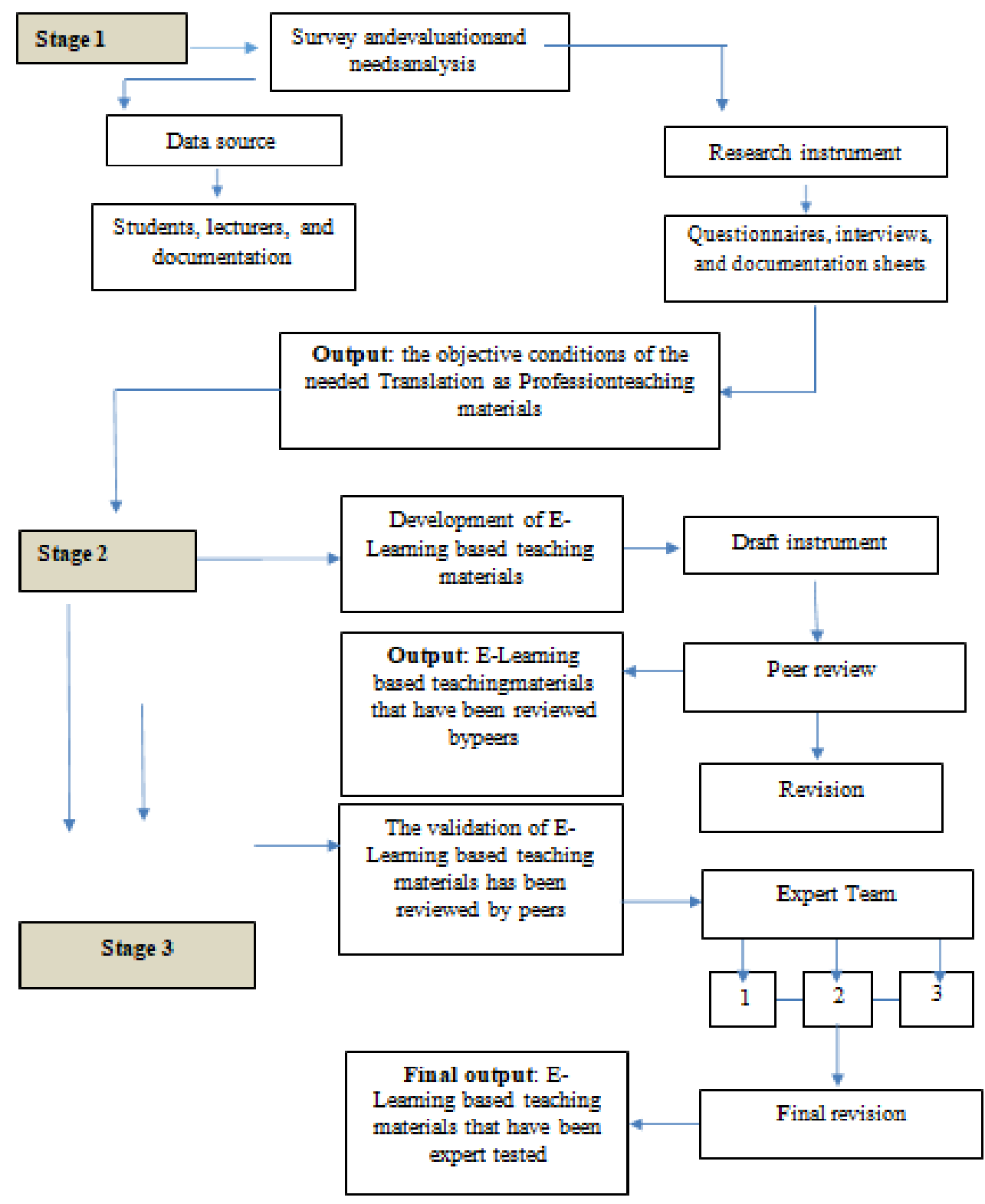

Chart 2. Fishbone Diagram Research Flow Chart 




Chart 3. Fishbone Diagram Research Flow Chart

\section{RESULTS AND DISCUSSION}

\section{Research Results}

Research which aims to develop Translation as Profession teaching materialsbased on ELearning is conducted using the Research and Development (R \& D) method. This research was carried out in 3 (three) stages where each stage has its own objectives and outputs.

The first stage-at this stage a survey and evaluation was conducted for 1) to know the objective conditions regarding the teaching materials for the translation as profession 2) to obtain data and information about the E-Learning-based Translation as Profession teaching materials for students majoring in English. Output: data on student perceptions about the Translation as profession course as follows.

In the questionnaire used to collect early stage data, there are 7 questions. The following is data about student responses to these questions.

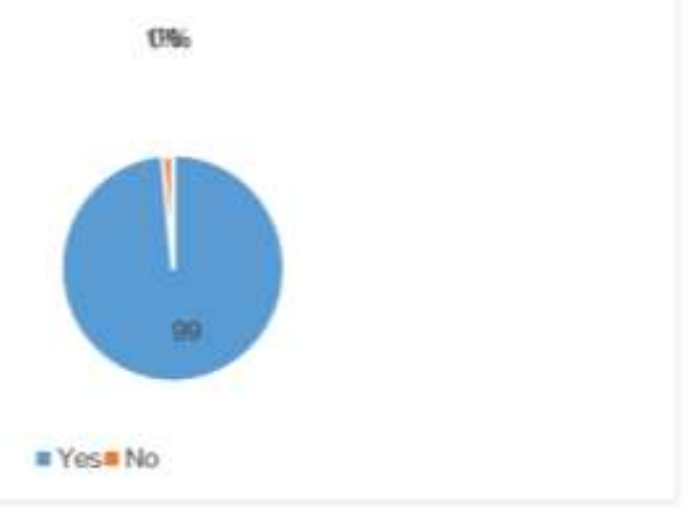

Chart 4. Students Interest in Translator

Chart 4 shows student responses to questions as students majoring in English Language and Literature, are you interested in translation, 66 students or 99\% said they are interested in Translation. Only 1 person or $1 \%$ said they were not interested in translation. 


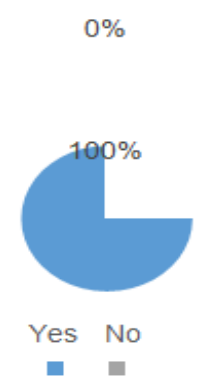

Chart 5. Students Opinion on Translator as Profession

2. Did you know that translator can be used as a profession?

Yes

67

Not

0

Chart 5 shows the responses of respondents to questions as a student majoring in English Language and Literature, did you know that translator can be used as a profession? 67 Students or 100\% said they were interested in Translation. Only 1 person or $1 \%$ knows that translation can be used as a profession

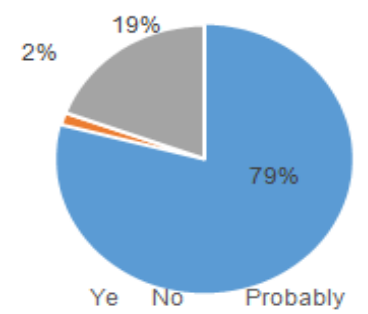

Chart 6. Students Opinion on Are You Interested as a Professional Translator

3. Are you interested in becoming a professional translator?

$\begin{array}{ll}\text { Yes } & 53 \\ \text { Not } & 1 \\ \text { Maybe } & 13\end{array}$

Chart 6 shows the respondent's answer to the question Are you interested as a profession $\varepsilon$ translator. 53 students or $79 \%$ stated that they are interested in becoming a professionc translator. 1 says no and 13 say they might be interested in becoming translator. 




Chart 7. Interest to be Professional Translator

4. Do you know how to become a professional translator?

$\begin{array}{ll}\text { Yes } & 16 \\ \text { Not } & 51 \\ \text { Maybe } & 0\end{array}$

Chart 7 shows the respondent's answer to the question Do you know how to become a professional translator. 16 students $24 \%$ or stated that they know how to become a professional translator. 51 people or $76 \%$ said they were not.

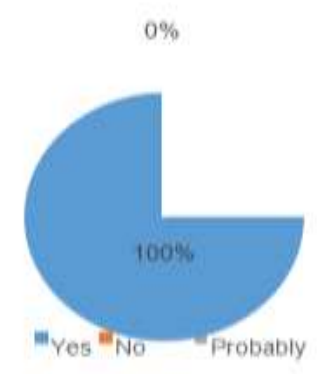

Chart 8. Workshop on the Introduction of Translation as Profession

5.Do you need a workshop on the introduction of Translation as Profession?

$\begin{array}{ll}\text { Yes } & 67 \\ \text { Not } & 0 \\ \text { Maybe } & 0\end{array}$

Chart 8 shows the respondent's answer to the question Do you need a workshop on introduction as a professional translator. All respondents stated that they needed a workshop 
Chart 9. Workshop on how to Translate a Text in a Professional Manner

6.Do you need a workshop on how to translate a text in a professional manner?

$\begin{array}{ll}\text { Yes } & 66 \\ \text { Not } & 1 \\ \text { Maybe } & 0\end{array}$

Chart 9 shows the respondents' answers to the questions. Do you need a workshop on how to translate texts in a professional manner? 66 Respondents or $99 \%$ said they needed it and only 1 said he didn't need it.

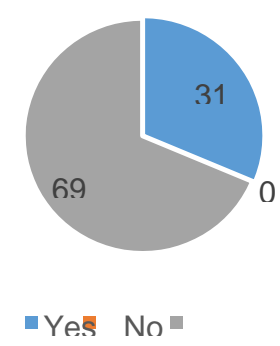

Chart 10. The Competencies Needed to Become a Professional Translator

7. Do you know the competencies needed to become a professional translator?

$\begin{array}{ll}\text { Yes } & 21 \\ \text { Not } & 0 \\ \text { Probably } & 46\end{array}$

Chart 10 shows the respondents' answers to the question whether you know the competencies needed to become a professional translator. 21 Students or $31 \%$ said they knew, 46 said they did not and 13 respondents respond that they probably know the competencies.

Second stage is designing and developing E-Learning-based teaching materials for students majoring in English. In the process of developing E-Learning-based teaching materials for students majoring in English, reviewing assessment instruments by peers, and revising E-Learning-based teaching materials for students majoring in English. Output: ELearning-based teaching materials for students majoring in English that have been reviewed 
by peers.

The teaching materials in question nconsist of 12 chapters regarding Translation as Profession material such as Introduction to Translation as profession; The Basic Concepts and Terms of Translation as Profession; How to be Professional Translators; Competencies needed toa Professional Translator, How to translateText on Economy; How to Translate Text on Health and Environment, How to translate text on Education and Socio Cultural Context, How to translate text on Government issues, Internship Model in Institution having Translation service, Presentation on Internship Program.

The third or final stagea the validation of E-Learning-based Translation as Profession teaching materials for students majoring in English by a team of experts. The expert team consists of two experts in the field of seminars on language teaching.

Research is in the stage of making and validating teaching materials on various topics related to Translation as Profession such as Introduction to Translation as profession; The Basic Concepts and Terms of Translation as Profession; How to be Professional Translators; Competencies needed to a Professional Translator, How to translate Text on Economy; How to Translate Text on Health and Environment, How to translate text on Education and Socio Cultural Context, How to translate text on Government issues, Internship Model in Institution having Translation service, Presentation on Internship Program. Regarding the prospective English teachers' perspectives on the teaching material for Translation as Profession Subject of in nine topics, 96,6\% or 29 of them view that all the materials are very important for them.

\section{CONCLUSION}

Based on the results of the research conducted, prospective English teachers' perspective on the teaching materials for Translation as Profession Subject is high in the Department of English Language and Literature, FBS Unimed. This shows that really need teaching materials for the E learning-based Translation as Profession course which can improve students' knowledge and abilities in doing translation. Regarding the prospective English teachers'perspectives on the teaching material for Translation as Profession Subject of in nine topics, $96,6 \%$ or 29 of them view that all the materials are very important for them. The teaching material has been validated tobe able to achieve learning objectives with the validation result is 4.3 and is categorized as very good.

\section{Suggestions}

For lecturers, it is hoped that this research can be used as a reference in teaching courses Translation as Profession for fifth semester students. For students, the teaching materials produced in this study can be used as a learning resource in the subject Translation as Profession For other researchers, this research can be used as a reference for conducting research and producing more perfect research.

\section{REFERENCES}

Andrew,M.(2003).Shouldwebeusingweb-basedlearningtosupplementface-to-face teaching of undergraduates? Accessed from cblis.uniza.sk/cblis-cd- old / 2003 / 3.PartB / Papers / ICT ... / Andrew.pdf. Retrieved11/02/2013. 
Atkins, DE, Brown, JS, \& Hammond, AL (2007). A review of the open educational resources (OER) movement: Achievements, challenges, and new opportunities. Accessedfromhttp://www.hewlett.org/uploads/files/ReviewoftheOERMovement.pdf on $11 / 02 / 2013$

Baker, M. (1992). In Other Words: A Coursebook on Translation. London: Routledge. Borg, WR, \& Gall, MD (1983). Educational Research: An Introduction (4ed). London:

Longman.

Creswell, JW (2003). Research Design: Qualitative, Quantitative, and Mixed Methods approaches (2nd ed). London: Sage Publications.

Creswell, John W. (2010). Reserch Design: Qualitative, Quantitative, and Mixed Approaches. Third Edition. Yogyakarta: Student Library. Translation: Ahmad Wafaid.

Davidson-Shivers, GV, Rasmussen, KL (2006). Web-Based Learning: Design, Implementation, and Evaluation. New Jersey: Pearson Merrill Prentice Hall.

Dick, W., Carey, L., Carey, JO (2005). The Systematic Design of Instruction (sixth edition). Boston: Pearson.

Directorate of Research and Community Service, Directorate General of Higher Education, Ministry of Education and Culture. (2013). Guidelines for the implementation of research and community service in higher education editions IX. Jakarta: DP2M Dikti.

Duan, Z. (2011). Task-based teaching of English-Chinese translation under "caliberoriented education to success" based on Web. Advanced Research on Electronic Commerce, Web Applications, and Communication, Communications in Computer and Information Science, Volume 143, p. 377, accessed from adsabs.harvard.edu/abs/2011arec.conf..377D on 16/02/2013

Hall, B. (1997). Web-based Training Cookbook. John Wiley \& Sons.

Hatim, B. (2001). Teaching and Researching Translation. Essex: Pearson Education Limited. Hatim, B., \& Mason, I. (1997). The Translator as Communicator. London: Routledge.

Hatim,B.\&Munday,J.(2004).Translation:AnAdvancedResourceBook.NewYork: Routledge. Hoed, BH (2006). Translation and Culture. Jakarta: Pustaka Jaya.

Karnedi. (2011). Analysis of Text in Translation. Jakarta: UT Publishing Center.

Kelly,D.(2005).Handbook for Translator Trainers.Manchester: St.Jerome Publishing.

Khan, BH (2001). Web-based Training. Educational TechnologyPublications. Micu, CS, Sinu. R. Web-based methods and tools in teaching translation and interpreting.

The 7th International Conference on Virtual Learning ICVL 2012, accessed from www.icvl.eu/2012/.../ICVL_ModelsAndMethodologies_paper11.pdf date 16/02/2013

Munday, J. (2001). Introducing Translation Studies. New York: Routledge. Newmark,

P. (1988). A Textbook of Translation. Hertfordshire: Prentice Hall.

Nord, C. (1991). Text Analysis In Translation: Theory, Methodology, and Didactic Application of a Model for Translation-oriented Text Analysis. Amsterdam: Rodopi.

Nord, C. (1997). Translation as a purposeful activity. Manchester: St. Jerome

Oppenheim, AN (1992). Questionnaire Design, Interviewing and Attitude Measurement. London: Pinter Publishers.

Rusman, Kurniawan, D., Riyana, C. (2012). Information and Communication Technology Based Learning. Jakarta: Rajawali Press.

Suparman, MA (2012). Educators' Guide \& Educational Innovators: Modern Instructional Design. Jakarta: Erlangga.

Silverman, D. \& Marvasti, A. (2008). Doing Qualitative Research: A Comprehensive Guide. California: Sage Publications. 
Tsai, S. \& Machado, P. (2013). E-learning, online learning, web-based learning, or distance learning: Unveiling the ambiguity in current terminology. Accessed from cblis.uniza.sk/cblis-cd-old/2003/3.PartB/Papers/ICT.../Andrew.pdf on 11/02/2013

UNESCO\&COL. (2011).Guide lines for Open Educational Resources (OER) in Higher Education. France \& Canada: UNESCO \&COL.

Open University. Open University Strategic Plan 2010-2021. Jakarta: Open University. Strategic Plan 2010-2021: Operational Plan 2010-2013. Open University. (2013) Distance Open Education Research Master Plan. 